\title{
FORUM
}

\section{Decline of monarch butterflies overwintering in Mexico: is the migratory phenomenon at risk?}

\author{
LINCOLN P. BROWER, ${ }^{1}$ ORLEY R. TAYLOR, ${ }^{2}$ ERNEST H. WILLIAMS, ${ }^{3}$ \\ DANIEL A. SLAYBACK,${ }^{4}$ RAUL R. ZUBIETA ${ }^{5}$ and M. ISABEL \\ RAMÍREZ ${ }^{6}{ }^{1}$ Department of Biology, Sweet Briar College, Sweet Briar, VA, USA, ${ }^{2}$ Department of Ecology \& \\ Evolutionary Biology, University of Kansas, Lawrence, KA, USA, ${ }^{3}$ Department of Biology, Hamilton College, Clinton, NY, \\ USA, ${ }^{4}$ Science Systems and Applications, Inc., Biospheric Sciences Branch, NASA Goddard Space Flight Center, Greenbelt, \\ MD, USA, ${ }^{5}$ Posgrado en Ciencias Biologicas, Universidad Nacional Autonoma de Mexico, Coyoacan, Mexico D.F., Mexico \\ and ${ }^{6}$ Centro de Investigaciones en Geografia Ambiental, Universidad Nacional Autonoma de Mexico, Antigua Carretera a \\ Patzcuaro, Morelia, Michoacan, Mexico
}

\begin{abstract}
During the 2009-2010 overwintering season and following a 15-year downward trend, the total area in Mexico occupied by the eastern North American population of overwintering monarch butterflies reached an all-time low. Despite an increase, it remained low in 2010-2011.

2. Although the data set is small, the decline in abundance is statistically significant using both linear and exponential regression models.

3. Three factors appear to have contributed to reduce monarch abundance: degradation of the forest in the overwintering areas; the loss of breeding habitat in the United States due to the expansion of GM herbicide-resistant crops, with consequent loss of milkweed host plants, as well as continued land development; and severe weather.

4. This decline calls into question the long-term survival of the monarchs' migratory phenomenon.
\end{abstract}

Resúmen. 1. Durante la temporada invernal 2009-2010, y siguiendo una tendencia a la baja de 15 años, la superficie total ocupada por mariposas monarca en México, provenientes del este América del Norte, llegó a su punto más bajo. A pesar de su incremento, dicha superficie siguió siendo baja en 2010-2011.

2. Aunque que el conjunto de datos disponibles es aún pequeño, esta disminución de la abundancia de mariposas es estadísticamente significativa, tanto si se usan modelos de regresión lineales como exponenciales.

3. Hay tres factores que parecen haber contribuido con esta tendencia de reducción del número de mariposas: la degradación de bosque en las áreas de invernación en México; la pérdida de hábitat de reproducción en los Estados Unidos, debido a la expansión de cultivos genéticamente modificados resistentes a herbicidas, con la consiguiente pérdida de las plantas hospederas de algodoncillo, y por continuos cambios en el uso del suelo no favorables para ellas; $y$, las recientes condiciones climáticas severas.

4. Esta disminución hace que nos cuestionemos sobre la posibilidad de supervivencia a largo plazo del fenómeno migratorio de las mariposas monarca.

Key words. Conservation, endangered biological phenomenon, habitat, Lepidoptera, migration, monitoring.

Correspondence: Ernest H. Williams, Department of Biology, Hamilton College, Clinton, NY 13323-1218, USA. E-mail: ewilliam@hamilton.edu 


\section{The decline in monarch abundance}

Wilcove (2008) has warned of the potential collapse of numerous animal migrations, including the unique migration and overwintering biology of the eastern North American population of the monarch butterfly, Danaus plexippus L. (Lepidoptera: Danainae). During the 2009-2010 season and following a 15-year downward trend, the total area of overwintering colonies reached an all-time low (Rendón-Salinas et al., 2010; Fig. 1). Yearly monarch abundance is assessed by measuring the combined area occupied by all known overwintering colonies in Mexico, and these data have been published online by World Wildlife Fund-Mexico since the 1994-1995 overwintering season, with data to 2001 also available in Garcia-Serrano et al. (2004). The average area occupied by the butterflies over the past 17 years is 7.24 ha, with a maximum of 20.97 ha during the 1996-1997 season and a minimum of 1.92 ha during the 2009 2010 season, and recovery to only 4.02 ha during the 2010-2011 season (Rendón-Salinas et al., 2011). The 1996-1997 overwintering season was monitored by Garcia-Serrano and Mora-Alvarez (1999) and also by a separate federal team of investigators (PROFEPA) (reference in Bojorquez et al., 2003), and we are confident that it was the largest recorded over the 17 years for which we have an adequate database. All of the past 7 years have been below the 17-year average. We have analysed these data and found that the decline is statistically significant.

To assess the time dependency of the measurements of colony area, we considered two regression models using the 17 years' data from Rendón-Salinas et al. (2010, 2011), with 1994 as year 1: a linear model, because it provides the simplest relationship between the time and area variables, and an exponential model, because it is the model frequently used to analyse population growth. We first examined the data for independence of successive years' measurements and found no evidence of autocorrela- tion (Durbin-Watson test, 4-d $=1.538$, with critical $\mathrm{dU}=$ 1.371; $P>0.05)$. Both linear and exponential regressions showed a significant decline in total colony area (Fig. 1; analysed with SPSS 2010): the linear model $y=11.89-0.52 x$ was significant at $P=0.018$, with $F_{1,15}=6.989$, and the exponential model $y=11.52 \mathrm{e}^{(-0.071 x)}$ was significant at $P=0.015$, with $F_{1,15}=7.601$. The $r^{2}$ values were 0.318 and 0.336 , respectively. We also ran polynomial regression models, but they did not increase $r^{2}$

Reliable information on colony sizes and locations is available since the 1994-1995 overwintering season; earlier information was gathered on increasing numbers of colonies as they were discovered by diverse groups of investigators with variable expertise. Even though the data span only 17 years, the decline is statistically significant. The regressions remain significant when either extreme measurement (high in 1996-1997 or low in 2009 2010 ) is removed (linear model, $P=0.032$ or 0.042 ; exponential model, $P=0.040$ or 0.049 ). We believe that all the measurements we have analysed are reasonably reliable. Continued monitoring will, of course, strengthen conclusions about trends in monarch abundance.

\section{Factors leading to declining abundance}

Three factors are implicated in the downward trend in the monarch's abundance: (i) the loss of and reduction in quality of critical overwintering habitat in Mexico through extensive illegal logging; (ii) the widespread reduction of breeding habitat in the United States due to continuing land development and the killing of the monarch's principal larval foodplant, the common milkweed Asclepias syriaca L. (Asclepiadaceae), because of increased use of glyphosate herbicide to kill weeds growing in genetically engineered, herbicide-resistant crops; and (iii)

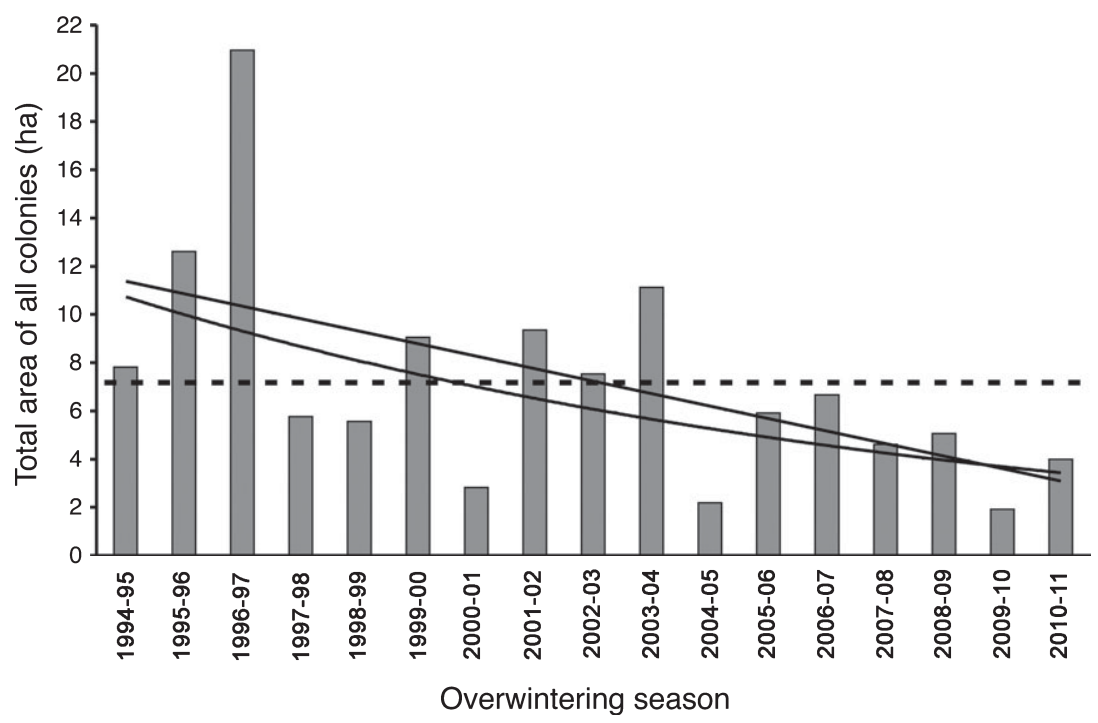

Fig. 1. The total annual area occupied by overwintering monarch butterflies from 1994 through 2011 has declined significantly, with the all-time smallest area reported during the 2009-10 overwintering season. The dashed line shows the 17-year average (7.24 ha). Both linear (upper) and exponential (lower) regression lines are included (see text for regressions). 
periodic extreme weather conditions, such as those that occurred most recently in 2009, that decrease both the spring breeding in Texas and the subsequent spring and summer breeding generations in the eastern USA and southern Canada.

\section{Forest degradation}

On the 12 known massifs that host the butterfly colonies in Mexico (Slayback et al., 2007), illegal logging has eliminated overwintering habitats on several and severely degraded them on others. For example, between 1971 and 1999, 44\% of the high quality over-wintering forest was degraded within the area that became protected as the Monarch Butterfly Special Biosphere Reserve by presidential decree in 1986 (Brower et al., 2002). Then, between 2001 and 2009, after the new 2000 presidential decree enlarged the Reserve core zone to 13552 ha, 1349 ha $(10 \%)$ were severely degraded or clear cut (Anonymous, 2009). Colony areas that have been entirely lost include several on the north face of Cerro Pelon (Ramirez et al., 2008; L.P. Brower \& D. Slayback, unpubl. aerial reconnaissance and satellite imagery) and at least three areas in the Lomas de Aparacio area on the southern portion of the Sierra Campanario (Brower et al., 2008). Colony areas that have been logged to the point at which few monarchs still aggregate include the west face of Cerro Pelon and the south face of Cerro Altamirano. Even the two principal ecotourism colony areas, Rosario and the Sierra Chincua, have been degraded by incremental logging over the past two decades (L.P. Brower, in prep.).

\section{Loss of breeding habitat in the United States}

Seiber et al. (1986) and Malcolm et al. (1993) determined through thin layer chromatography that 85 and $92 \%$, respectively, of 394 and 382 overwintering monarch butterflies in Mexico had fed as larvae on the Common Milkweed, Asclepias syriaca. The importance of $A$. syriaca reflects history of the landscape. A rich pre-colonial milkweed flora was widely distributed, with 29 species of Asclepias, most of them grassland species (Woodson, 1954; Hartman, 1986) native to the late summer breeding range of the monarch (Malcolm et al., 1989, 1993; Wassenaar \& Hobson, 1998). However, ploughing of the prairies and deforestation led to an increase in the distribution and abundance of A. syriaca (Brower, 1995), which Woodson referred to as the pre-eminent weedy North American milkweed. Now with an increasingly patchy distribution, this species is the dominant milkweed in the monarch's eastern North American breeding range.

A survey in 1999 of habitats containing this milkweed species showed that the number of monarchs produced per ha in maize (corn) and soya (soybean) fields was as high or higher than that of other habitats (Oberhauser et al., 2001). Genetically modified glyphosate resistant (GR) soya and maize (e.g. Monsanto's Roundup Ready crops) were rapidly adopted by growers after 1999, resulting in a significant reduction of $A$. syriaca and the loss of monarch breeding habitats in these croplands. Much of the combined acreage of soya and maize (60-70 million ha per year) is used in rotation, and this rotation in combination with the high adoption rate of GR soya ( $>70 \%$ by 2002 , presently $92 \%$ ) and maize (presently 23\%) (U.S.D.A., 2010a) has all but eliminated $A$. syriaca from 40 million ha of these croplands (Taylor, 2008). Both Hartzler (2010) and J.M. Pleasants (in prep.) have documented the drastic reduction of $A$. syriaca growing in glyphosate-treated fields in Iowa; Hartzler recorded a $90 \%$ loss from 1999 to 2009, and Pleasants measured a 79\% loss from 2000 to 2009. We conclude that, because of the extensive use of glyphosate herbicide on crops that are genetically modified to resist the herbicide, milkweeds will disappear almost completely from croplands. Furthermore, Zalucki and Lammers (2010) have estimated with models that the large-scale elimination of milkweeds in agricultural and surrounding landscapes has the effect of increasing the search time for host plants by monarch females with the result that realised fecundity is reduced.

In addition, milkweed habitat has been lost due to increasing demand for biofuels. Conservation Reserve Program (CRP) area has been decreased by 2.3 million ha since 2006 (U.S.D.A., 2010b) and as yet undetermined but large areas of grassland and rangeland have been converted to biofuel crops, especially maize (Stubbs, 2007). Over this same interval, maize and soya planting increased by more than 5 million ha (U.S.D.A., 2010a, and previous year reports from the USDA National Agricultural Statistics Service). Coupled with the habitat lost to development, which has been calculated as nearly 1 million ha each year from 1992 to 2007 (U.S.D.A., 2003, 2009), these losses add to at least 56 million ha (roughly 220000 square miles). This is more than one-fifth of the estimated eastern North American summer breeding range of the monarch (Brower, 1999). The cost to the monarch population of habitat loss due to GR crops, increased planting of maize and soya, in addition to development is surely significant.

\section{Extreme weather}

Severe cold threatens the survivorship of overwintering monarchs, and spring and summer weather that is too cold or too hot lowers breeding season survivorship and fecundity and alters larval growth rates. In the spring of 2009, first-generation monarchs in Texas were negatively affected in March by above normal temperatures. Subsequent low temperatures in the corn (maize) belt, the third lowest in 42 years, limited growth of the summer generations. These climatic factors severely reduced the numbers of butterflies in the fall migration to Mexico (Taylor, 2009).

Then, during the 2009-2010 overwintering season, the butterflies were subjected to a record-breaking amount of precipitation during the dry season (Brower et al., 2010). From 31 Oct 2009 through 31 Mar 2010, $577 \mathrm{~mm}$ of precipitation fell, compared to $40 \mathrm{~mm}$ and $20 \mathrm{~mm}$ over the same time span for the previous two seasons, as recorded by the electronic weather station (Model 232; WeatherHawk, Logan, UT, USA) we established on the Sierra Chincua at the El Llano las Papas Field Station $\left(100^{\circ} 16^{\prime} 5^{\prime \prime} \mathrm{W}, 19^{\circ} 39^{\prime} 42^{\prime \prime} \mathrm{N}\right)$. This station is at the same elevation $(3160 \mathrm{~m})$ and $2-4 \mathrm{~km}$ from a principal overwintering area

(C) 2011 The Authors

Insect Conservation and Diversity (C) 2011 The Royal Entomological Society, Insect Conservation and Diversity, 5, 95-100 
(Brower et al., 2009). From 31 January to 4 February 2010, the WeatherHawk recorded $360 \mathrm{~mm}$ of rain. Associated heavy winds blew down hundreds of oyamel fir trees in the core zone of the Reserve (pers. obs., Mar 2010). A low temperature of $-3.2{ }^{\circ} \mathrm{C}$ occurred as the skies cleared immediately after the storm; the second morning, after the butterflies had dried, the temperature dropped to $-6{ }^{\circ} \mathrm{C}$.

The 5-day storm caused major flooding, landslides, structural damage, and loss of human life (Elorriaga, 2010). Local observers (e.g., Rodriguez, 2010) reported that high winds associated with this and several less severe storms scattered the butterflies from their bough and trunk clusters. According to Anderson and Brower (1996), the low temperature recorded immediately after the storm could have killed $5-10 \%$ of the wetted butterflies. Had the drop to $-6.0^{\circ} \mathrm{C}$ occurred while the butterflies were still wet, rather than on the second morning when they were dry, more than $90 \%$ mortality could have occurred. Interviews of scientists, tour leaders, and tourists who visited the overwintering monarch colonies subsequent to the storm led Taylor (2010) to conclude that $50 \%$ of the monarchs died. Thus, this storm, combined with the lowest number of overwintering monarchs yet recorded, could have resulted in such a reduction in the number of remigrating spring butterflies that recovery of the eastern North American population would have required several breeding seasons. Nevertheless, the butterflies increased to 4.02 ha in 2010-2011, although this value is still well below the 17-year average of 7.24 ha. The frequency of severe precipitation events is likely to increase with climate change (Oberhauser \& Peterson, 2003; IPCC, 2007).

\section{Outlook}

The unique migratory phenomenon of the monarch butterfly has been designated as an endangered biological phenomenon (Brower \& Malcolm, 1991). Concerns about breeding habitat and overwintering forest habitat loss were central issues in a Commission for Environmental Cooperation conference held in Morelia during December 2007 that led to the North American Monarch Butterfly Conservation Plan (Oberhauser et al., 2008). Increasing international interest in the North American monarch phenomenon also led to the designation on 8 July 2008 of the Monarch Butterfly Biosphere Reserve as a World Heritage Site (Anonymous, 2008). In this paper, we have presented an analysis of the long-term trend in monarch abundance, a decline that exists despite some fluctuation year-to-year. The combination of lowered numbers of fall migrants, the illegal logging in the overwintering region, the severe losses of breeding habitat due both to GM crops and development, and the near miss of catastrophic mortality by the 2010 storm suggest that better stewardship is needed to assure the future of the monarch migratory phenomenon.

\section{Acknowledgements}

We thank Rosendo Caro, Director of the Monarch Butterfly Biosphere Reserve, for facilitating our research and World Wild- life Fund-Mexico, and especially Eduardo Rendon, for continued colony monitoring. Zach Dietz, Department of Mathematics, Hamilton College, provided advice on statistical analyses. We are also grateful to two anonymous reviewers for valuable suggestions. Support to LPB was provided by the October Hill Foundation and NSF grant DEB-0415340 to Sweet Briar College with L.P. Brower and L.S. Fink as principal investigators. EHW was supported by the Christian A. Johnson Fund at Hamilton College. MIR was supported by DGAPAPAPIIT (IN114707).

\section{References}

Anderson, J.B. \& Brower, L.P. (1996) Freeze-protection of overwintering monarch butterflies in Mexico: critical role of the forest as a blanket and an umbrella. Ecological Entomology, 21, 107-116.

Anonymous. (2008) Monarch Butterfly Biosphere Reserve. UNESCO World Heritage Centre, United Nations, New York. $<$ http://whc.unesco.org/en/list/1290> 10 February 2011.

Anonymous. (2009) Deforestacion y degradacion forestal en la Reserva de La Biosfera Mariposa Monarca 2008-2009. World Wildlife Fund Mexico Report (WWF/FMCN) of the Fondo para la Conservacion de la Mariposa Monarca, 1-3. World Wildlife Fund-Mexico. < http://www.wwf.org.mx/wwfmex/descargas/res_degradation_deforestacion_monarca_2008-2009. pdf $>26$ February 2010.

Bojorquez, L.A., Brower, L.P., Castilleja, G., Sánchez-Colón, S., Hernández, M., Calvert, W.H., Díaz, S., Gómez-Priego, P., Alcantar, G., Melgarejo, E.D., Solares, M.J., Gutiérrez, L. \& Juárez, M.D.L. (2003) Mapping expert knowledge: redesigning the monarch butterfly biosphere reserve. Conservation Biology, 17, 367-379.

Brower, L.P. (1995) Understanding and misunderstanding the migration of the monarch butterfly (Nymphalidae) in North America: 1857-1995. Journal of the Lepidopterists' Society, 49, 304-385.

Brower, L.P. (1999) Biological necessities for monarch butterfly overwintering in relation to the Oyamel forest ecosystem in Mexico. Paper Presentations: 1997 North American Conference on the Monarch Butterfly (Morelia, Mexico) (ed. by J. Hoth, L. Merino, K. Oberhauser, I. Pisanty, S. Price and T. Wilkinson), pp. 11-28. The Commission for Environmental Cooperation, Montreal, Canada.

Brower, L.P., Castilleja, G., Peralta, A., Lopez-Garcia, J., Bojorquez-Tapia, L., Diaz, S., Melgarejo, D. \& Missrie, M. (2002) Quantitative changes in forest quality in a principal overwintering area of the monarch butterfly in Mexico: 1971 to 1999. Conservation Biology, 16, 346-359.

Brower, L.P., Fink, L.S., Ramirez, I., Zubieta, R. \& Slayback, D. (2010) Weather storms and monarchs. Monarch Watch Blog, 21 February 2010. < http://monarchwatch.org/blog/2010/02/ weather-storms-and-monarchs $>1$ March 2010.

Brower, L.P. \& Malcolm, S.B. (1991) Animal migrations: endangered phenomena. American Zoologist, 31, 265-276.

Brower, L.P., Slayback, D. \& Ramirez, I. (2008) Image of the Day (Deforestation in the Monarch Butterfly Biosphere Reserve in Mexico). < http://earthobservatory.nasa.gov/IOTD/ view.php?id $=8506>11$ November 2010 .

Brower, L.P., Williams, E.H., Slayback, D.A., Fink, L.S., Ramirez, M.I., Zubieta, R.R., Limon Garcia, M.I., Gier, P., 
Lear, J.A. \& Van Hook, T. (2009) Oyamel fir forest trunks provide thermal advantages for overwintering monarch butterflies in Mexico. Insect Conservation and Diversity, 2, 163175.

Elorriaga, E.M. (2010) Siguen en albergues 3 mil 200 habitantes de Angangueo; el Ejército termina plan DN-III. In: Peridico La Jornada, 23 Febrero, p. 27. Mexico City <http://www. jornada.unam. $\mathrm{mx} / 2010 / 02 / 23 /$ index.php?section $=$ estados\&arti cle $=027 n 2$ est $>18$ October 2010

Garcia-Serrano, E. \& Mora-Alvarez, X. (1999) Monitero de las colonias de mariposa en sus sitios de invernacio en Mexico. Paper Presentations: 1997 North American Conference on the Monarch Butterfly (Morelia, Mexico) (ed. by J. Hoth, L. Merino, K. Oberhauser, I. Pisanty, S. Price and T. Wilkinson), pp. 177-182. Commission for Environmental Cooperation CEC, Montreal, Canada.

Garcia-Serrano, E., Reyes, J.L. \& Mora-Alvarez, B.X. (2004) Locations and area occupied by monarch butterflies overwintering in Mexico from 1993 to 2002. The Monarch Butterfly: Biology and Conservation (ed. by K. Oberhauser and M. Solensky), pp. 129-133. Cornell University Press, Ithaca.

Hartman, R.L. 1986. Asclepiadaceae R. Br., the milkweed family. Flora of the Great Plains (ed. by T.M. Barkley), pp. 614-637. University of Kansas Press, Lawrence.

Hartzler, R.G. (2010) Reduction in common milkweed (Asclepias syriaca) occurrence in Iowa cropland from 1999 to 2009. Crop Protection, 29, 1542-1544.

IPCC (2007) Contribution of Working Group I. Fourth Assessment Report of the Intergovernmental Panel on Climate Change, 2007 (ed. by S. Solomon, D. Qin, M. Manning, Z. Chen, M. Marquis, K.B. Averyt, M. Tignor and H.L. Miller), pp. 1-996. Cambridge University Press, Cambridge, UK.

Malcolm, S.B., Cockrell, B.J. \& Brower, L.P. (1989) Cardenolide fingerprint of monarch butterflies reared on common milkweed, Asclepias syriaca L. Journal of Chemical Ecology, 15, 819-853.

Malcolm, S.B., Cockrell, B.J. \& Brower, L.P. (1993) Spring recolonization of eastern North America by the monarch butterfly: successive brood or single sweep migration? Biology and Conservation of the Monarch Butterfly (ed. by S.B. Malcolm and M.P. Zalucki), pp. 253-267. Science Series No. 38, Natural History Museum of Los Angeles County, Los Angeles.

Oberhauser, K.S., Cotter, D., Davis, D., Décarie, R., Behnumea, A.E., Galino-Leal, C., Gallina Tessaro, M.P., Howard, E., Lauriault, J., Maczieski, W., Malcolm, S., Martínez, F., González, J.M., McRae, M., Nernberg, D., Pisanty-Baruch, I., Ramírez, I., Reyes, J.J. \& Wilson, V. (2008) North American Monarch Conservation Plan. Commission for Environmental Cooperation, Montreal, Canada.

Oberhauser, K. \& Peterson, A.T. (2003) Modeling current and future potential wintering distributions of eastern North American monarch butterflies. Proceedings of the National Academy of Sciences USA, 100, 14063-14068.

Oberhauser, K.S., Prysby, M.D., Mattila, H.R., Stanley-Horn, D.E., Sears, M.K., Dively, G., Olson, E., Pleasants, J.M., Lam, W.F. \& Hellmich, R. (2001) Temporal and spatial overlap between monarch larvae and corn pollen. Proceedings of the National Academy of Sciences USA, 98, 1191311918.

Ramirez, M.I., Miranda, R. \& Zubieta, R. (2008) Vegetación y Cubiertas del Suelo, 2006 (1:75000). Serie Cartográfica Monarca. Volumen I. Segunda Edición. MBSF-CIGA-UNAM-
INE-SEMARNAT-UNESCO. < http://www2.ine.gob.mx/publicaciones/ consultaPublicacion.html?id_pub $=541>18$ November 2010 .

Rendón-Salinas, E., Valera-Bermejo, C.A., Cruz-Piña, M. \& Martinez-Meza, F. (2011) Monitoreo de las colonias de hibernación de mariposa monarca: Superficie forestal de ocupación en Diciembre de 2010. World Wildlife Fund - Mexico, Mexico City. < http://www.wwf.org.mx/wwfmex/descargas/rep-monitoreo-superficie-colonias-mariposa-monarca-alianza-wwf-telcel-DIC 2010.pdf $>16$ February 2011.

Rendón-Salinas, E., Valera-Bermejo, C.A. \& Martinez-Meza, F. (2010) Monitoreo de las Colonias de Hibernación de Mariposa Monarca: Superficie Forestal de Ocupación en Diciembre de 2009. World Wildlife Fund - Mexico, Mexico City. <http:// www.wwf.org.mx/wwfmex/descargas/rep-monitoreo-superficiecolonias-mariposa-monarca-2009-2010.pdf > 26 February 2010.

Rodriguez, R.R. (2010) Vientos y deslaves arrasaron con casi 120 hectáreas en la zona núcleo de la Mariposa Monarca (Winds and Mudslides Degrade150 hectares in Monarch Biosphere Reserve). In Cambio de Michoacan, p.1, Morelia, Mexico.

Seiber, J.N., Brower, L.P., Lee, S.M., McChesney, M.M., Cheung, H.T.A., Nelson, C.J. \& Watson, T.R. (1986) Cardenolide connection between overwintering monarch butterflies from Mexico and their larval foodplant, Asclepias syriaca. Journal of Chemical Ecology, 12, 1157-1170.

Slayback, D.A., Brower, L.P., Ramirez, M.I. \& Fink, L.S. (2007) Establishing the presence and absence of overwintering colonies of the monarch butterfly in Mexico by the use of small aircraft. American Entomologist, 53, 28-39.

SPSS (2010) IBM SPSS Statistics 18. IBM Corp., Somers, New York.

Stubbs, M. (2007) Land conversion in the Northern Plains. Congressional Research Service Report for Congress RL33950. $<$ http://lugar.senate.gov/services/pdf_crs/ag/12.pdf $>1$ November 2010.

Taylor, C. (2008) Roundup-ready crops and resistant weeds. Monarch Watch Blog 17 January 2008. < http://monarch watch.org/blog/2008/01/roundup-ready-crops-and-resistant-wee ds/> 7 November 2010.

Taylor, C. (2009) Monarch Population Status. Monarch Watch Blog. Tuesday, 20 October 2009. < http://monarchwatch.org/ blog/2009/10/monarch-population-status-5/> 1 March 2010.

Taylor, C. (2010) Monarch Population Status. Monarch Watch Blog. Saturday 10 July 2010. < http://monarchwatch.org/blog/ 2010/07/monarch-population-status-9/> 4 November 2010.

U.S.D.A. (2003) Summary Report: 2001 National Resources Inventory, Natural Resources Conservation Service, Washington, DC, and Center for Survey Statistics and Methodology, Iowa State University, Ames, Iowa. < http://www.nrcs.usda.gov/technical/NRI/2001/nri01dev.html > 1 November 2010.

U.S.D.A. (2009) Summary Report: 2007 National Resources Inventory, Natural Resources Conservation Service, Washington, DC, and Center for Survey Statistics and Methodology, Iowa State University, Ames, Iowa. < http://www.nrcs.usda.gov/technical/ NRI/2007/2007_NRI_Summary.pdf > 1 November 2010.

U.S.D.A. (2010a) Acreage. National Agricultural Statistics Service (NASS). < http://usda.mannlib.cornell.edu/usda/nass/Acre/ 2010s/2010/Acre-06-30-2010.pdf\#page $=24>9$ November 2010

U.S.D.A. (2010b) Monthly CRP acreage report, Conservation Reserve Program, Farm Service Agency. <http://www.fsa.usda.gov $/$ FSA $/$ webapp?area $=$ home\&subject $=$ copr\&topic $=$ rnscss $>3$ November 2010. 
Wassenaar, L.I. \& Hobson, K.A. (1998) Natal origins of migratory monarch butterflies at wintering colonies in Mexico: new isotopic evidence. Proceedings of the National Academy of Sciences USA, 95, 15436-15439.

Wilcove, D.S. (2008) No Way Home: The Decline of the World's Great Animal Migrations. Island Press/Shearwater Books, Washington.

Woodson, R.E. (1954) The North American species of Asclepias L. Annals of the Missouri Botanical Garden, 41, 1-211.
Zalucki, M.P. \& Lammers, J.H. (2010) Dispersal and egg shortfall in Monarch butterflies: what happens when the matrix is cleaned up? Ecological Entomology, 35, 84-91.

Accepted 21 February 2011

First published online 20 March 2011

Editor: Simon R. Leather

Associate editor: Phil DeVries 